\title{
Dynamics of the South Java Coastal Current revealed by RAMA observing network
}

\author{
Putri Adia Utari ${ }^{1}$, Dedi Setiabudidaya ${ }^{2}$, M. Yusup Nur Khakim ${ }^{2}$, and Iskhaq Iskandar ${ }^{1,2, *}$ \\ ${ }^{1}$ Program Studi Ilmu Lingkungan, Program Pascasarjana, Universitas Sriwijaya, Sumatera Selatan, Palembang, Indonesia \\ ${ }^{2}$ Jurusan Fisika, Fakultas Matematika dan Ilmu Pengetahuan Alam, Universitas Sriwijaya, Kampus Inderalaya, Ogan Ilir, \\ Sumatera Selatan, Indonesia
}

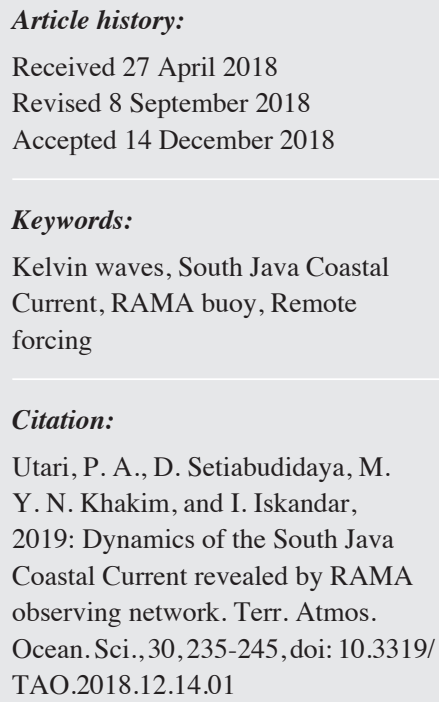

\begin{abstract}
A series of Acoustic Doppler Current Profiler (ADCP) measurements moored along the equatorial and coastal wave-guide were used to evaluate the dynamics of the South Java Coastal Current (SJCC). 17-month (December 2008 to May 2010) data from the ADCP off South Java give some insights into the dynamics of the SJCC. The data reveal high variability in the upper $100 \mathrm{~m}$ depth, where the core of the SJCC is located. In addition, robust intraseasonal variations at period of $70-100$ days dominate the SJCC variation. Consistent with previous studies, dynamics of the SJCC is strongly driven by the equatorial waves from the Indian Ocean. Due to a failure in ADCP measurement, the equatorial moorings only have a short overlapping period with the South Java mooring, from the boreal fall 2009 until spring 2010. Nevertheless, the data still exhibit coherence variations in which the strong eastward flow during the boreal fall 2009 and the spring 2010 that observed off South Java can be traced back to the equatorial region. Further analysis confirmed the important role of the remote winds from the equatorial Indian Ocean in affecting the SJCC variations through a generation of eastward propagating wind-forced equatorial Kelvin waves. Nevertheless, the contribution of the local wind forcing is not negligible in generating the SJCC variations.
\end{abstract}

\section{INTRODUCTION}

The South Java Costal Current (SJCC) is seasonally varying coastal currents observed along the south coast of Java (Wyrtki 1962). Strong eastward SJCC was observed during the peak of northwest monsoon season, and it weakened during the southeast monsoon. Note that the SJCC reveals seasonal variation along the southern coast of Java. Along the western coast of Sumatra and along the southern coast of Timor, only its amplitude reveals seasonal variation. Throughout the year, the SJCC flows southeastward along the western coast of Sumatra, while along the southern coast of Timor it flows westward (Quadfasel and Cresswell 1992).

The SJCC is among the poorest observed eastern boundary current system. The first study, conducted by Klaus Wyrtki during 1959 - 1961 through a project so-called Marine Investigations of the South China Sea and the Gulf

\footnotetext{
* Corresponding author

E-mail: iskhaq@mipa.unsri.ac.id
}

of Thailand, revealed a distinct seasonal variation of the SJCC (Wyrtki 1962). In December, when the northwesterly winds dominate atmospheric circulation over the region, the SJCC flows eastward and reach its peak in February. Wyrtki (1962) suggested that the eastward extension of the SJCC only reaches the eastern end of the Java Island. As the southeasterly winds started to develop in April in the eastern Indonesian region, the SJCC weakened and its axis shifted northward close to the coast of Java. The SJCC still shows a sporadic eastward current event when the southeasterly winds reached its peak in July to August.

The first direct measurement was conducted from March 1997 through March 1998 (Sprintall et al. 1999). This measurement used a series of current meters at 55, 115 , and $175 \mathrm{~m}$ depth. From this limited vertical resolution, it is found that the strongest currents were observed at the depth of $55 \mathrm{~m}$. The authors show robust southeastward current during spring and fall 1997 associated with the windforced equatorial Kelvin waves. Interestingly, the observed 
currents reveal that the fall southeastward currents were relatively weaker and longer lasting compared to the spring southeastward currents. It should be noted that the period of measurement encompassed the evolution of strong El Niño/positive Indian Ocean Dipole events. Therefore, the observed characteristic of the SJCC might not represent the normal condition.

Meanwhile, modeling study has shown that the SJCC is a relatively shallow current along the southern coast the Lesser Sunda Island. It is confined in the upper $150 \mathrm{~m}$ depth with maximum speed was found at a depth of about $50 \mathrm{~m}$ (Iskandar et al. 2006). It also shows spatial variation, in which the strongest current was observed off south Java. In addition, the SJCC is regulated by the Indonesian Throughflow (ITF) that exits from the Lombok Strait. Only a few part of the SJCC could penetrate further eastward through the Ombai Strait as previously reported (Sprintall et al. 2010).

Considering the important role of the SJCC in circulating heat and water masses in the southeastern boundary of the Indian Ocean, the Research Moored Array for African-Asian-Australian Monsoon Analysis and Prediction (RAMA) deployed an Acoustic Doppler Current Profiler (ADCP) in the south of Java Island. The deployment of an ADCP off south Java was designed to measure the magnitude and variability of the Java upwelling system. It is expected that understanding the Java upwelling system may improve our understanding on the coupled air-sea interaction in that region, which is co-located with the eastern pole of the Indian Ocean Dipole (Saji et al. 1999).

Using a relatively higher vertical resolution of observed currents from the near surface down to a depth of
$136 \mathrm{~m}$ in the south coast of Java, this study is designed to address the following questions. How are the spatial (vertical) and temporal variations of the SJCC? Could the proposed driving mechanism of the SJCC variability obtained from the modeling study be applied to this direct measurement? The rest of this paper is organized as follow. Section 2 provides comprehensive information about the data used in this study. In section 3, we evaluated the time variations of the observed SJCC. Discussion on the dynamical forcing of the SJCC is presented in section 4 and the final section is reserved for the conclusion.

\section{DATA}

\subsection{The ADCP Data}

An Acoustic Doppler Current Profiler (ADCP) was deployed off South Java to capture the variability of the SJCC. This mooring is part of the Research Moored Array for African-Asian-Australian Monsoon Analysis and Prediction (RAMA) (McPhaden et al. 2009). The mooring was mounted at $106.75^{\circ} \mathrm{E}, 8.5^{\circ} \mathrm{S}$ as shown by a green star in Fig. 1 . The mooring has 15 levels from $24 \mathrm{~m}$ down to $136 \mathrm{~m}$ with vertical resolution of $8 \mathrm{~m}$. It provides data at daily resolution for a period from 15 December 2008 to 16 May 2010, which encompasses a short-lived 2009/10 El Niño event (Kim et al. 2011). Our evaluation on the surface wind variations during the evolution of 2009/10 El Niño event did not show any significant change on the surface wind variations. Although the ADCP only recorded currents in the upper layer, it captures the core of SJCC and most of the vertical range of the SJCC. Previous studies have shown that the core of SJCC is

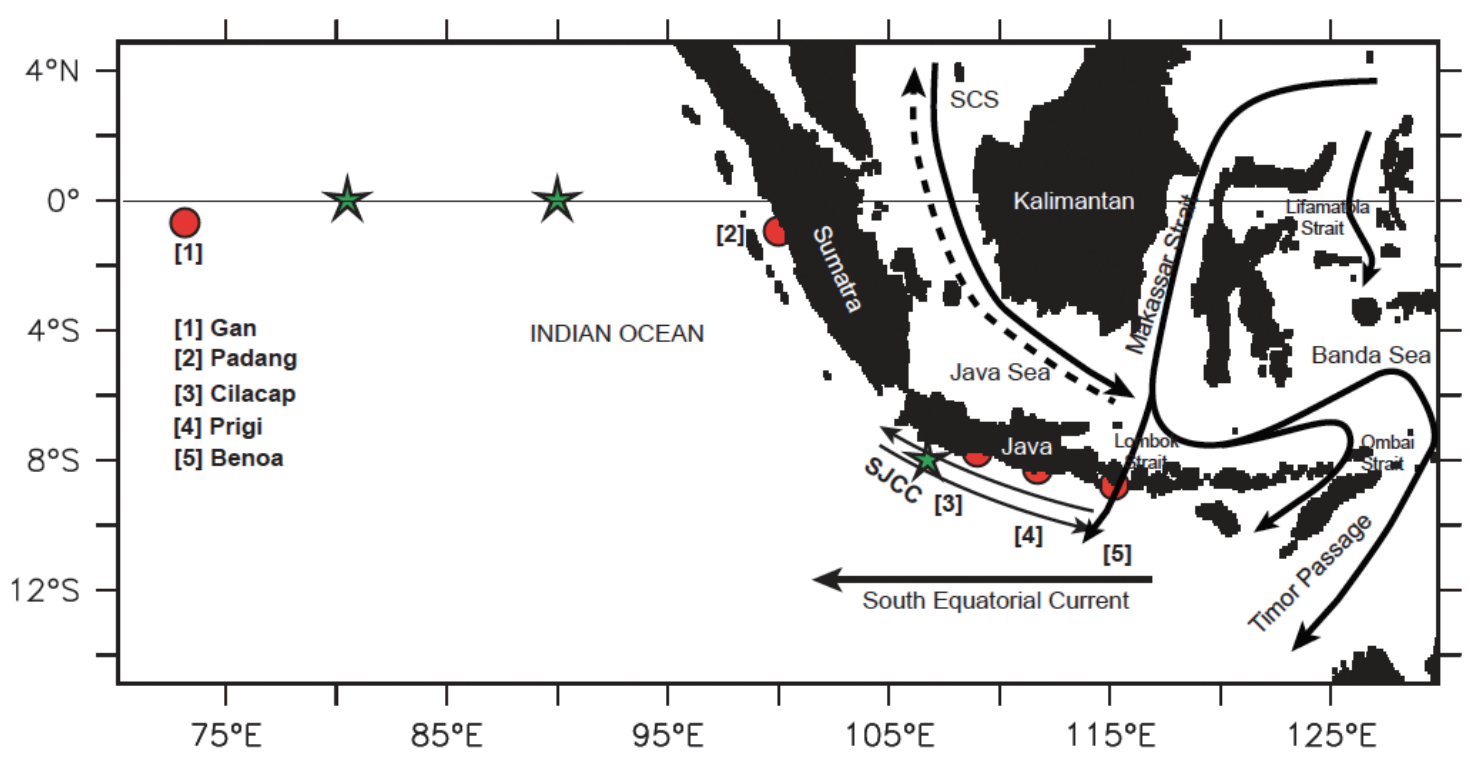

Fig. 1. Schematic representation of identified currents (e.g., the South Java Coastal Current and the South Equatorial Current) and the Indonesian Throughflow in the Indonesia Sea. Locations of the ADCP moorings along the equator $\left(80.5\right.$ and $\left.90^{\circ} \mathrm{E}\right)$ and in the south of Java $\left(106.75^{\circ} \mathrm{E}, 8.5^{\circ} \mathrm{S}\right)$ are indicated by green stars, and the tidal stations at 5 locations in the central equtaorial Indian Ocean and along the coast of Sumatra, Java and Bali are shown by red circles. 
at a depth of about $50 \mathrm{~m}$ and located close to the south coast of Java. The current is gradually decreasing with depth and it is much weaker below $100 \mathrm{~m}$ depth (Sprintall et al. 1999; Iskandar et al. 2006). In addition, earlier studies have also suggested that the SJCC has spatial and temporal variations. The strongest current was observed off south Java where the mooring is located. Meanwhile, the core of SJCC did not show significant depth variation (Quadfasel and Cresswell 1992; Iskandar et al. 2006). Note that this mooring also has much higher resolution compared to the previous measurement of the SJCC that has only 3 levels: 55, 115, and $175 \mathrm{~m}$ depths (Sprintall et al. 1999).

We also used two ADCP moorings mounted along the equatorial Indian Ocean at 80.5 and $90^{\circ} \mathrm{E}$ as shown by two green stars in Fig. 1 . The ADCP at $80.5^{\circ} \mathrm{E}$ has 5-m and daily vertical and temporal resolution, respectively (Nagura and Mcphaden 2008). The data is available from 30 - $175 \mathrm{~m}$ depth. Meanwhile, the ADCP mooring at $90^{\circ} \mathrm{E}$ recorded the currents from 40 - $300 \mathrm{~m}$ depth with vertical resolution of $10 \mathrm{~m}$ and temporal resolution of one day (Masumoto et al. 2005; Iskandar et al. 2009). Unfortunately, due to instrument failure the ADCP data along the equator have only limited overlapping data with those off South Java. The ADCP data from mooring mounted at $80.5^{\circ} \mathrm{E}$ have overlapping period with those mounted off South Java from 2 September 2009 to 16 May 2010 . On the other hand, the mooring at $90^{\circ} \mathrm{E}$ have shorter overlapping period, which are from 9 November 2009 to 16 May 2010. Note that for all ADCP data, we filled the short gaps (less than 10 days) by using temporal linear interpolation.

\subsection{Altimeter Data}

The sea surface height (SSH) data used in this study are merged data from available altimeter missions, namely Jason-1 and 2, TOPEX/Poseidon, Envisat, GFO, ERS-1 and 2, and Geosat. The data are derived from the Archiving, Validation and Interpretation of Satellite Oceanographic Data (AVISO) (http://www.aviso.oceanobs.com). The SSH data have temporal resolution of 7-day and spatial resolution of $0.25^{\circ} \times 0.25^{\circ}$ (Ducet et al. 2000). In this study, we used data from January 2009 to May 2010. In order to avoid the errors due to uncertainties in the geoid, we have removed the longterm means of the SSH.

\subsection{Surface Wind Data}

In order to evaluate dynamical forcing of the SJCC, we used daily surface winds from the National Centers for Environmental Prediction-National Center for Atmospheric Research (NCEP-NCAR) reanalysis (Kalnay et al. 1996). In this study, the surface wind data for the period of 1 January 2009 to 16 May 2010 with horizontal resolution of $2.5^{\circ} \times$ $2.5^{\circ}$ were utilized.

\subsection{Near-Surface Current}

The surface current data were provided by the Ocean Surface Current Analysis-Realtime (OSCAR) on $1^{\circ} \times 1^{\circ}$ spatial resolution (Bonjean and Lagerloef 2002). These current data were calculated based on geostrophic and thermal wind adjustment using a simplified dynamical upper ocean model, assuming quasi-steady dynamics. In this study, we used a 5-day gridded data from 1 January 2009 to 16 May 2010.

\subsection{Tide Gauge Data}

Daily tide gauge data observed at 5 tidal station located in the equatorial Indian Ocean and along the coast of Sumatra, Java and Bali Islands are used in this study (Fig. 1). The data are obtained from the University of Hawaii Sea Level Center and detailed locations of the tidal stations are presented in Table 1. In this study, we used the data for a period of 1 January 2009 to 31 May 2010. Note that the sea level anomaly was defined as a deviation from each daily climatological field of 1 January 2008 to 31 December 2010. In order to minimize the noise, we have applied 5-day running mean to the daily climatology data.

\section{RESULTS}

\subsection{Characteristics of the Observed South Java Coastal Current}

Figure 2 displays the zonal and meridional currents and alongshore winds at the mooring location off South Java. It is clear from Figs. 2a - b that both surface and subsurface zonal currents reveal robust intraseasonal variation. Strong eastward surface and subsurface currents were observed in February 2009, mid-April to mid-June 2009, mid-September to mid-October 2009, November 2009, January 2010, and April to May 2010 (Figs. 2a - b). On the other hand, strong westward currents were observed in January 2009, July to August 2009, mid-October to mid-November 2009, and February to mid-March 2010 (Figs. 2a - b). The zonal current variability was closely related to the alongshore winds. The observed eastward currents co-occurred with eastward alongshore winds, indicating the important role of the local wind forcing (Fig. 2a). However, the strong eastward zonal currents observed in November 2009 could not be explained by the local wind forcing only, suggesting a possible role of remote forcing from the equatorial region. It has been suggested that strong eastward equatorial jets forced by the westerly winds along the equator during monsoon breaks in April to May and October to November could reach the South Java region through the propagation of Kelvin waves (Iskandar et al. 2005; Sprintall et al. 2009).

The magnitude of the observed meridional currents is much weaker than that of the observed zonal currents. However, variability of the observed meridional currents reveals 
Table 1. Location of tidal station used in this study.

\begin{tabular}{ccc}
\hline No. & Name of tidal station & Location \\
\hline 1. & Gan Island & $0.69^{\circ} \mathrm{S}, 73.15^{\circ} \mathrm{E}$ \\
2. & Padang & $0.95^{\circ} \mathrm{S}, 100.37^{\circ} \mathrm{E}$ \\
3. & Cilacap & $7.75^{\circ} \mathrm{S}, 109^{\circ} \mathrm{E}$ \\
4. & Prigi & $8.28^{\circ} \mathrm{S}, 111.73^{\circ} \mathrm{E}$ \\
5. & Benoa & $8.77^{\circ} \mathrm{S}, 115.2^{\circ} \mathrm{E}$ \\
\hline
\end{tabular}

(a) Surface zonal current and alongshore wind off south Java

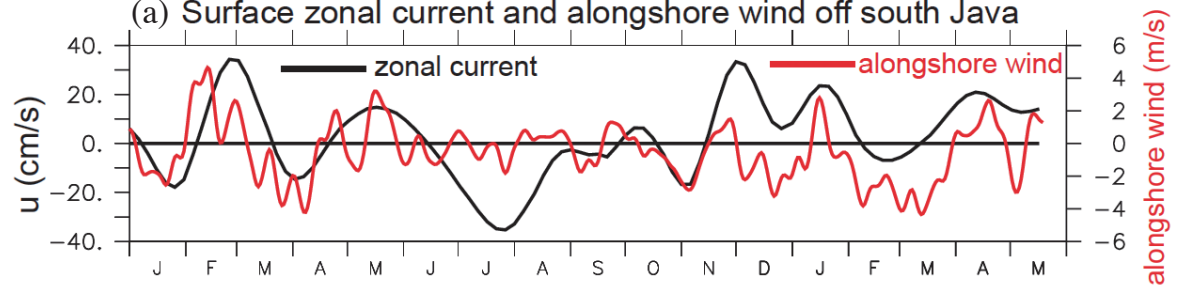

(b) ADCP zonal currents at $\left(8.5^{\circ} \mathrm{S}, 106.75^{\circ} \mathrm{E}\right)$

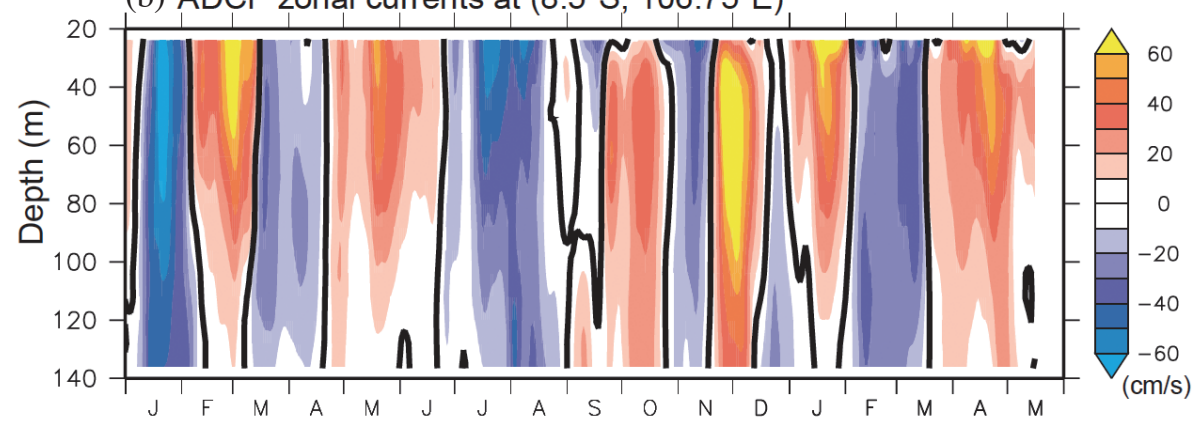

(c) Surface meridional currents

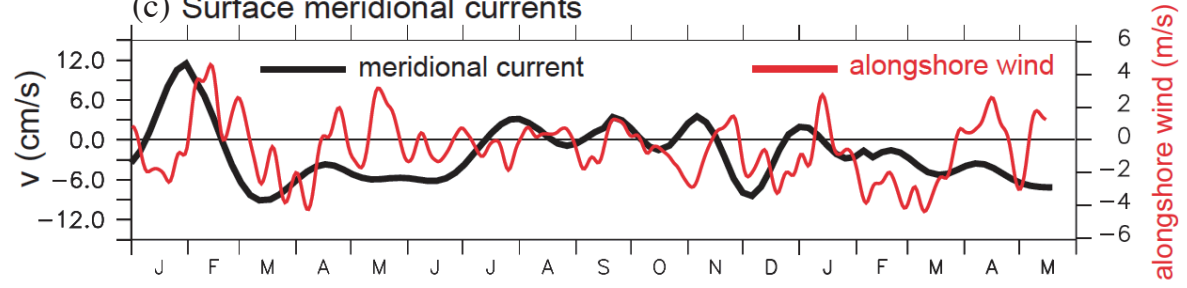

(d) ADCP meridional currents at $\left(8.5^{\circ} \mathrm{S}, 106.75^{\circ} \mathrm{E}\right)$

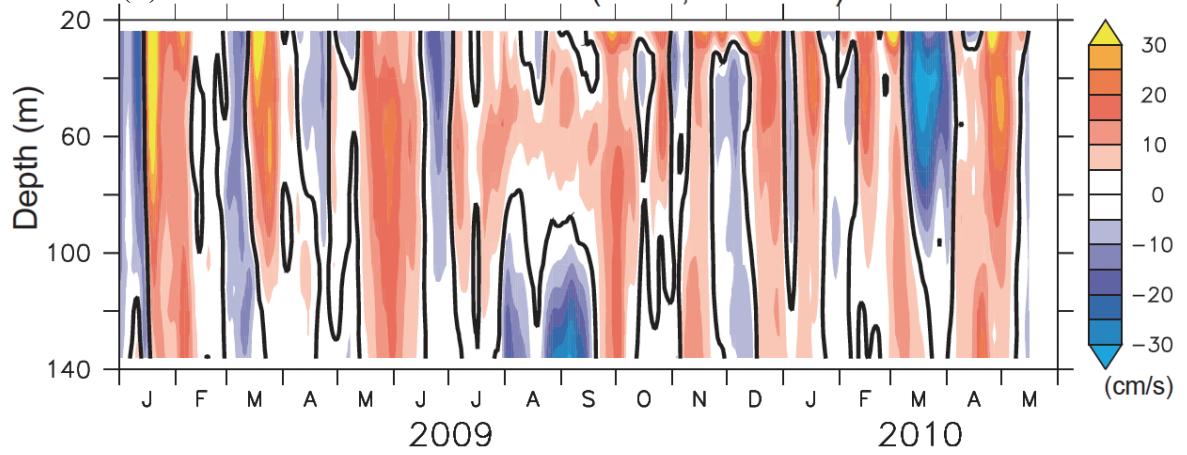

Fig. 2. (a) Time series of the near-surface zonal current from OSCAR and alongshore winds off south Java ( $\mathrm{cm} \mathrm{s}^{-1}$ ), (b) time-depth plot of the observed zonal currents from ADCP mooring off south Java. The eastward (westward) currents are shaded by reddish (bluish) color ( $\mathrm{cm} \mathrm{s}^{-1}$ ). The zero value is marked by the black contours. (c) - (d) same as in (a) - (b) except for the meridional components. 
shorter time-scale variation (Fig. 2d), although the OSCAR data could not capture this higher frequency variation (Fig. 2c). In addition, northward flow is dominant in the meridional currents below about $50 \mathrm{~m}$.

Figure 3 shows the vertical profiles of time averaged and standard deviation of the observed zonal and meridional currents at South Java. The mean zonal flows are eastward flow between the near-surface layer and $90 \mathrm{~m}$ (Fig. 3a). The maximum mean eastward flow is $8 \mathrm{~cm} \mathrm{~s}^{-1}$ and it is located at $40 \mathrm{~m}$ depth, corresponding to the core of the SJCC (Iskandar et al. 2006; Sprintall et al. 2009). The meridional mean flows are dominated by the northward flow in the entire layer (Fig. 3a). There are two maxima of northward flow. The first maximum is about $6 \mathrm{~cm} \mathrm{~s}^{-1}$ and it is located near the surface, while the second maximum located about $60 \mathrm{~m}$ depth is about $4 \mathrm{~cm} \mathrm{~s}^{-1}$. The standard deviation of the zonal and meridional currents indicated that the high variability is observed in the upper about $100 \mathrm{~m}$ depth, with maximum variability of the zonal currents co-located with the core of the SJCC (Fig. 3b). Magnitude of the standard deviation for the meridional currents is much smaller than that of the zonal currents.

Spectra of the zonal and meridional currents are shown in Fig. 4. Note that the spectra are calculated for the period of 15 December 2008 to 16 May 2010 and their spectra are estimated by smoothing with triangle filter. The spectrum of observed zonal currents shows distinct peaks within intraseasonal band of 70 - 100-day confined in in the upper $100 \mathrm{~m}$ depth (Fig. 4a). This result has been confirmed by previous modeling studies, which have shown the dominant 90-day variation in the SJCC variability (Qiu et al. 1999; Iskandar et al. 2006). Meanwhile, the spectrum of observed meridional current shows a distinct intraseasonal variation within 50 - 70-day in the upper about $80 \mathrm{~m}$ depth (Fig. 4b).
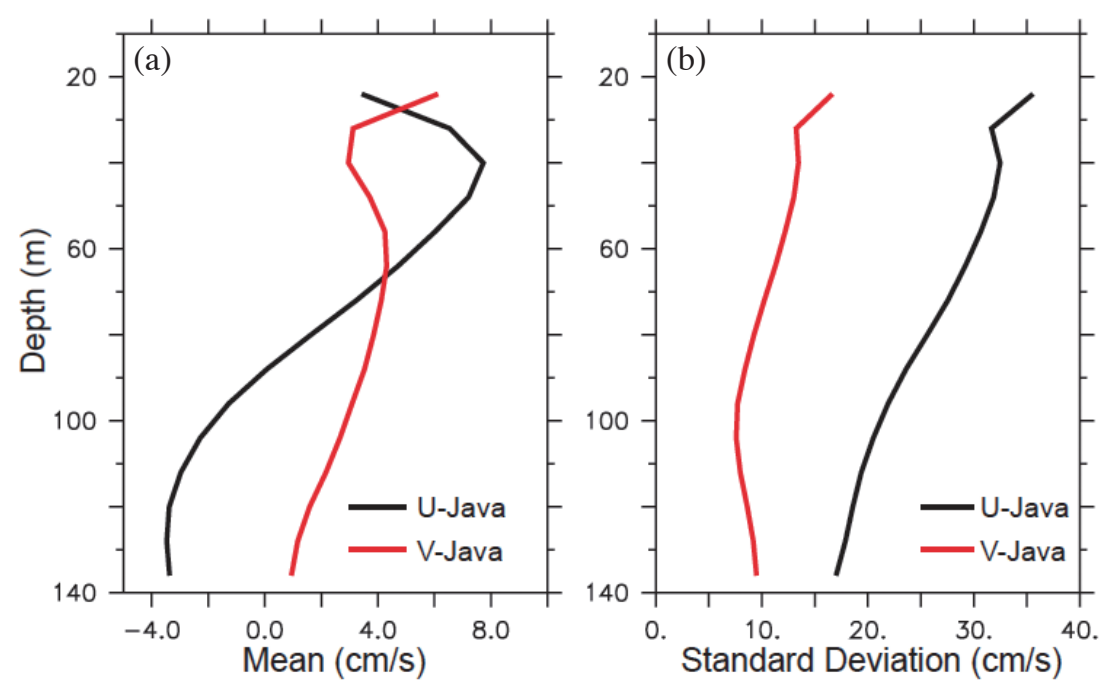

Fig. 3. Vertical profiles of (a) mean, and (b) standard deviation of the observed zonal and meridional currents off south Java.

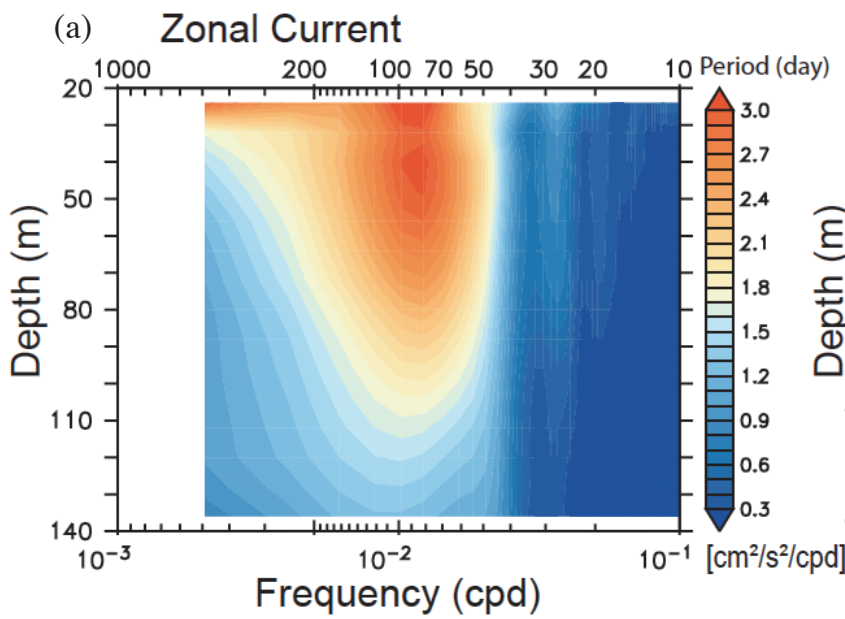

(b) Meridional Current

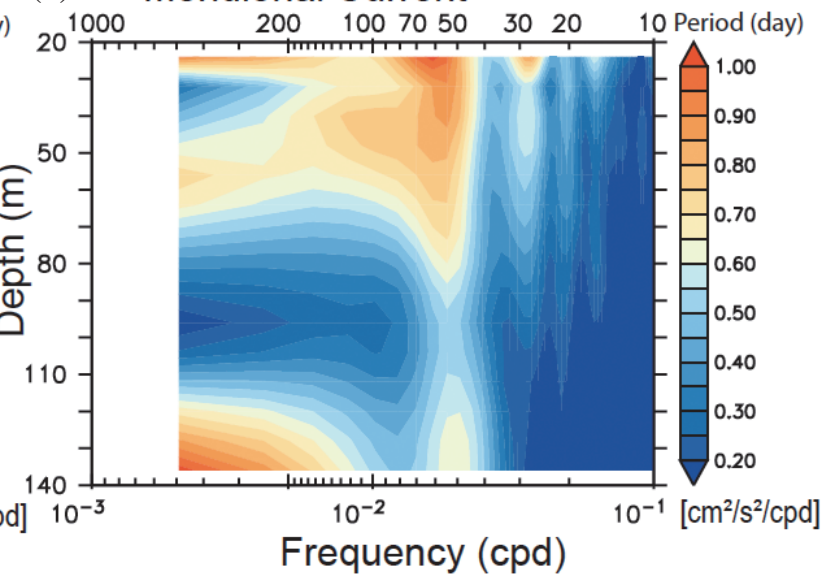

Fig. 4. Power spectra of the (a) zonal, and (b) meridional currents observed at $106.75^{\circ} \mathrm{E}, 8.5^{\circ} \mathrm{S}$ off south Java. 
In addition to the intraseasonal peak, spectral peaks at semiannual and annual periods are also clearly seen the observed zonal and meridional currents. This spectral peak is only observed in the upper layer. However, the energy in these spectral peaks is weaker than that in the intraseasonal peak. A limited-duration (17 months) of observed currents might prevent the identification of the semiannual and annual variations.

\subsection{Dynamical Forcing of the South Java Coastal Currents}

Previous studies have suggested that both remote windforcing from the equatorial Indian Ocean and local alongshore winds affect the variability of the SJCC (Qiu et al.
1999; Sprintall et al. 1999; Iskandar et al. 2006). In order to evaluate the forcing mechanism of the SJCC, we first calculate the correlation between vertically averaged upper layer zonal currents (surface to $100 \mathrm{~m}$ depth) observed by the RAMA buoy off South Java and those observed along the equatorial Indian Ocean at 80.5 and $90^{\circ} \mathrm{E}$ (Fig. 5). Note that due to big gaps in the zonal currents observed by the ADCP mounted along the equator, the correlation was calculated only for short data: from 2 September 2009 to 16 May 2010 for ADCP at $80.5^{\circ} \mathrm{E}$, and from 9 November 2009 to 16 May 2010 for $\mathrm{ADCP}$ at $90^{\circ} \mathrm{E}$. Nevertheless, the results show that the zonal currents observed off South Java are significantly correlated with those observed at 80.5 and $90^{\circ} \mathrm{E}$ along the equator, in which the variability in the South Java lags those in the equator by about 18 and 14 days, respectively

(a) Surface zonal current and zonal wind at $\left(0^{\circ} \mathrm{S}, 80.5^{\circ} \mathrm{E}\right)$

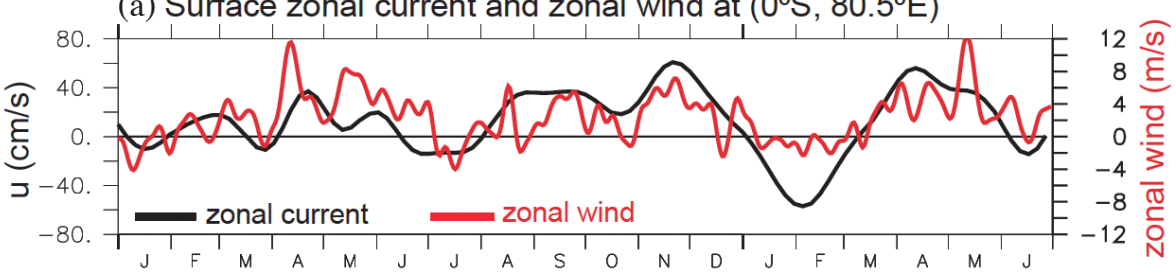

(b) ADCP zonal current at $\left(0^{\circ} \mathrm{S}, 80.5^{\circ} \mathrm{E}\right)$

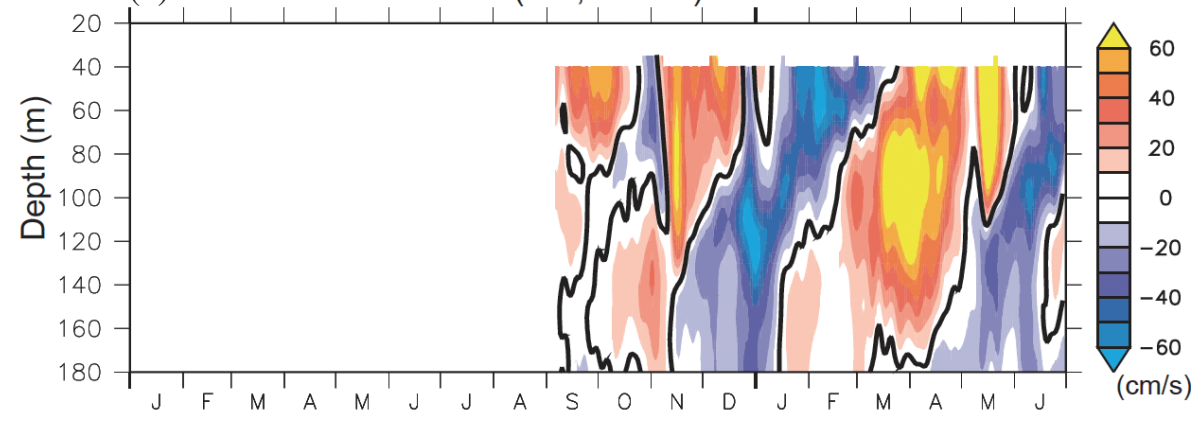

(c) Surface zonal current and zonal wind at $\left(0^{\circ} \mathrm{S}, 90^{\circ} \mathrm{E}\right)$

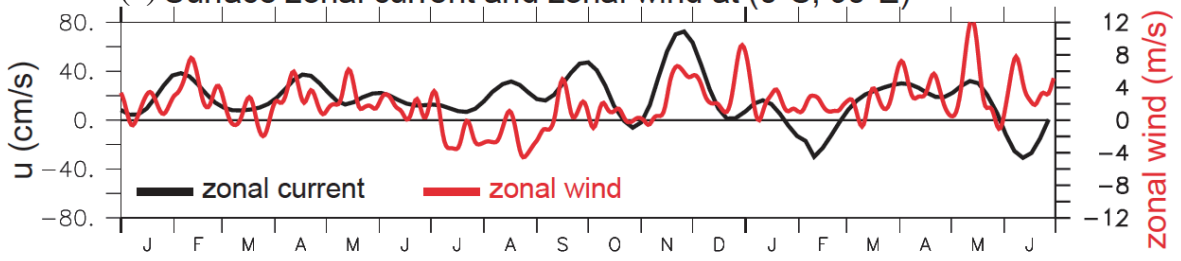

(d) ADCP zonal currents at $\left(0^{\circ} \mathrm{S}, 90^{\circ} \mathrm{E}\right)$

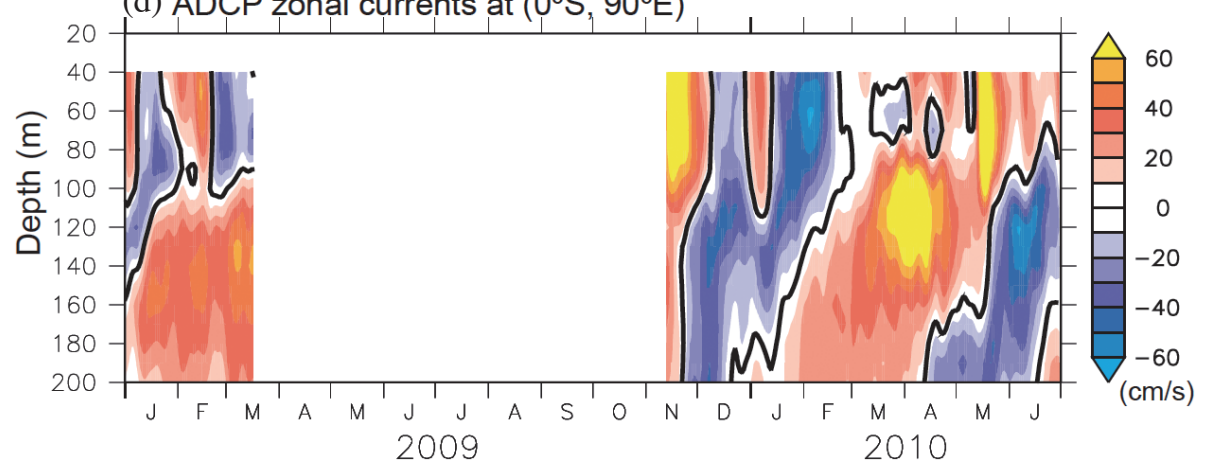

Fig. 5. Same as Fig. 2 except for the observed zonal currents and zonal wind at (a) - (b) $80.5^{\circ} \mathrm{E}$, and (c) - (d) $90^{\circ} \mathrm{E}$ on the equator. 
(Fig. 6). This indicates an eastward propagating signal with phase speed of about $2.37 \mathrm{~m} \mathrm{~s}^{-1}$, which is associated with the first baroclinic Kelvin waves.

To illustrate the role of remote and local forcing on the temporal variability of the SJCC, a lag correlation analysis was performed by correlating the surface winds, the SSH anomaly (SSHA) and the near-surface currents with the SJCC (Fig. 7). Note that the SJCC time series are defined as the vertically averaged zonal currents above $100 \mathrm{~m}$ depth. It is clearly shown that the remote wind forcing from the equatorial Indian Ocean plays important role in generating the SJCC variations as indicated by significant correlations between the SJCC and the surface winds. Nevertheless, contributions from the local wind forcing to the SJCC variations are not negligible (Figs. 7a - d). This result is in good agreement with the previous studies showing that both remote and local wind forcing are important in generating the SJCC variations (Sprintall et al. 1999; Iskandar et al. 2006).

The correlation between the SJCC and the SSHA and the near-surface currents can be interpreted in term of the equatorial wave dynamics (Fig. 7). At lag -20 days, the strong correlation between the SJCC and the SSHA and the near-surface currents is associated with the eastward propagation of the wind-forced downwelling equatorial Kelvin waves, indicated by positive SSHA (Fig. 7a). At the same time, two SSH minima are observed on either side of the central equator, which are a typical structure of upwelling Rossby waves. Strong eastward surface currents along the equator are also generated, which also indicate significant correlation with the SJCC (Fig. 7e). Ten days later (Fig. 7b), the downwelling Kelvin wave signals reached the western coast of Sumatra, part of their energy propagating poleward along the eastern boundary as downwelling coastal Kelvin waves and the remaining is reflected into interior Indian Ocean as a westward propagating downwelling Rossby waves. At lag 0 day (Fig. 7c), the Kelvin wave signals have arrived at the mooring location off South Java. Obviously, at lag +5 days the downwelling coastal Kelvin waves have propagated further poleward, while the eastern-boundrayreflected downwelling Rossby waves have propagated further westward (Fig. 7d).

Further insight into the eastward propagating signal from the equatorial region to the south of Java can be interpreted from sea level data obtained from a series of the tidal stations located in the equatorial Indian Ocean and along the coast of Sumatra and Java (Fig. 1). We evaluate sea level data for a period of January 2009 to May 2010 similar to that of ADCP data. It is shown that distinct positive sea level anomalies observed at the downstream tidal stations can be traced back to the equatorial region (Fig. 8). For example, positive sea level anomaly observed in the Benoa in January 2010 can be traced back to the Gan Island station. Similar behavior can be found for the signals observed in May/June and November 2009, as well as in March/April and May 2010.

The eastward propagating signal from the equatorial region to the SJCC region is further shown by the lag correlation of the sea level observed at each station pair along the equatorial and coastal waveguide (Fig. 9). The results show that the observed sea level at each station pair has significant correlation with a tendency for the observed signal at the upstream stations (western part) to lead those observed at the downstream stations (eastern part) along the coast. This indicates that there is an eastward propagating signal originating from the equatorial region. We then estimated the phase speed of those eastward propagating signals based on the time-lag correlation of the observed sea level at each stations pair as shown in Fig. 9. The mean phase speed is $2.67 \pm 0.31 \mathrm{~m} \mathrm{~s}^{-1}$ with $95 \%$ confidence limit (Thomson and Emery 2004). This phase speed corresponds well with the

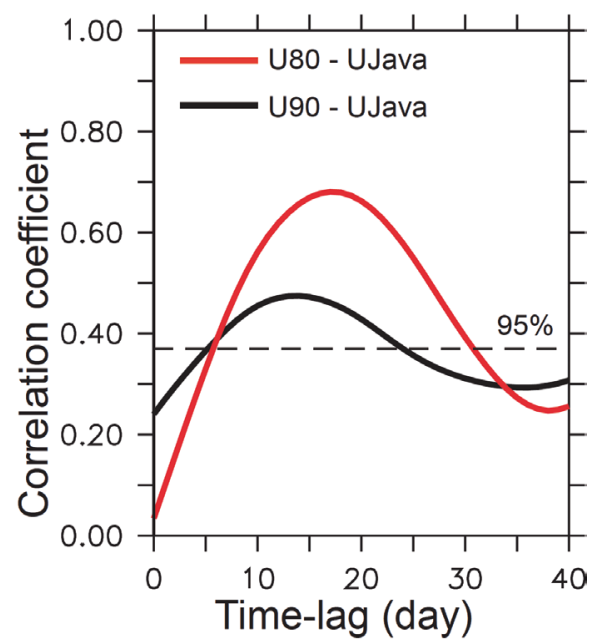

Fig. 6. Time-lag correlation of the averaged upper layer (upper $100 \mathrm{~m}$ depth) zonal currents observed at $106.75^{\circ} \mathrm{E}, 8.5^{\circ} \mathrm{S}$ off south $\mathrm{Java}$ and those observed at $80.5^{\circ} \mathrm{E}, 0^{\circ} \mathrm{S}$ (red) and $90^{\circ} \mathrm{E}, 0^{\circ} \mathrm{S}$ (black). The horizontal dashed lines indicate $95 \%$ confidence limits. 
(a) $\operatorname{Lag}=-20$ days

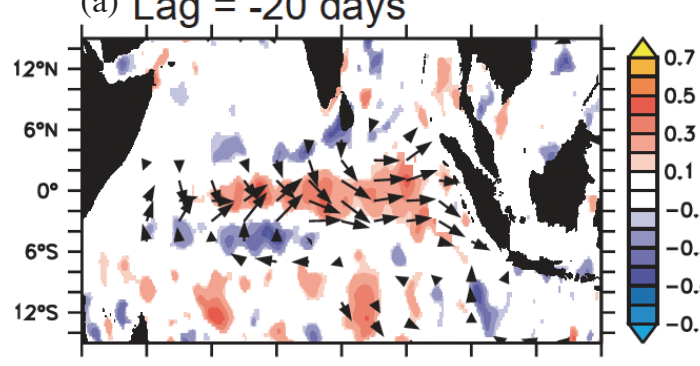

(b) Lag $=-10$ days

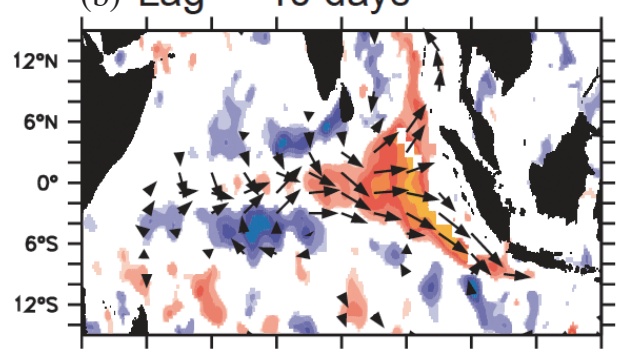

(c) $\mathrm{Lag}=0$ days

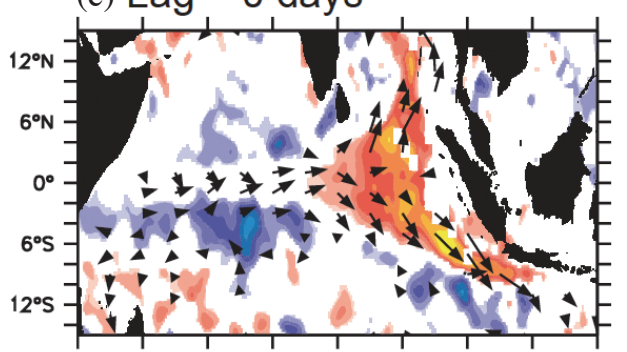

(d) $\operatorname{Lag}=+5$ days

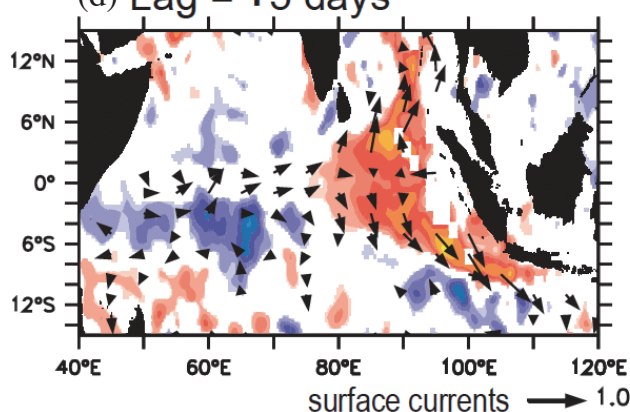

(e) $\operatorname{Lag}=-20$ days

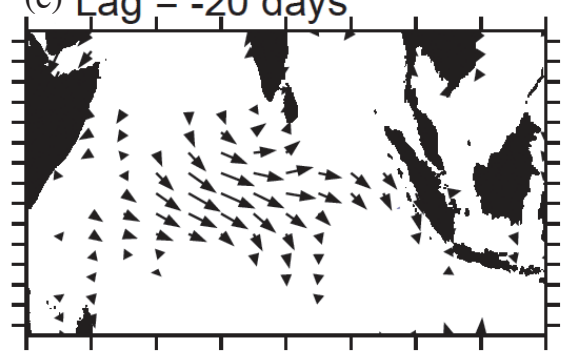

(f) $\operatorname{Lag}=-10$ days

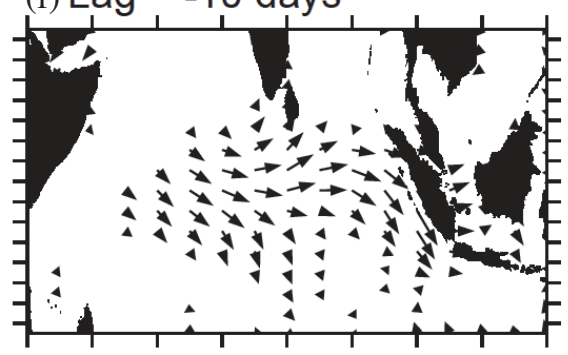

(g) Lag = 0 days

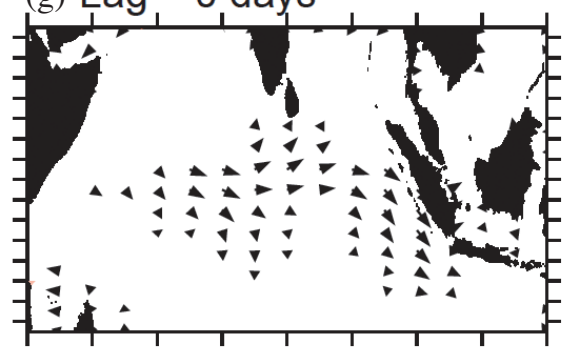

(h) $\operatorname{Lag}=+5$ days

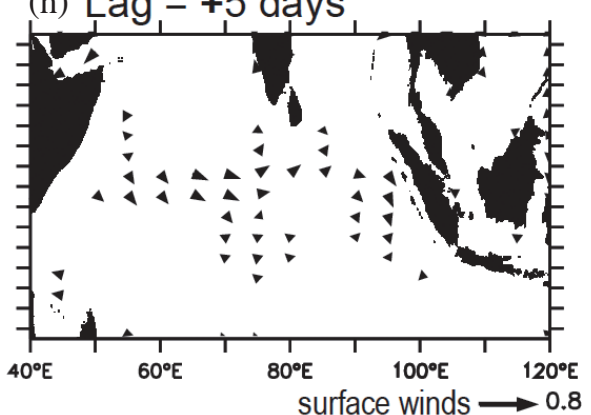

Fig. 7. Maps of the averaged upper layer (upper $100 \mathrm{~m}$ depth) zonal currents observed at $106.75^{\circ} \mathrm{E}, 8.5^{\circ} \mathrm{S}$ off south Java correlated with (a) - (d) sea surface height (shading) and surface winds (vector), (e) - (h) near-surface currents from OSCAR. Only correlations above 95\% confidence limit are shown. 

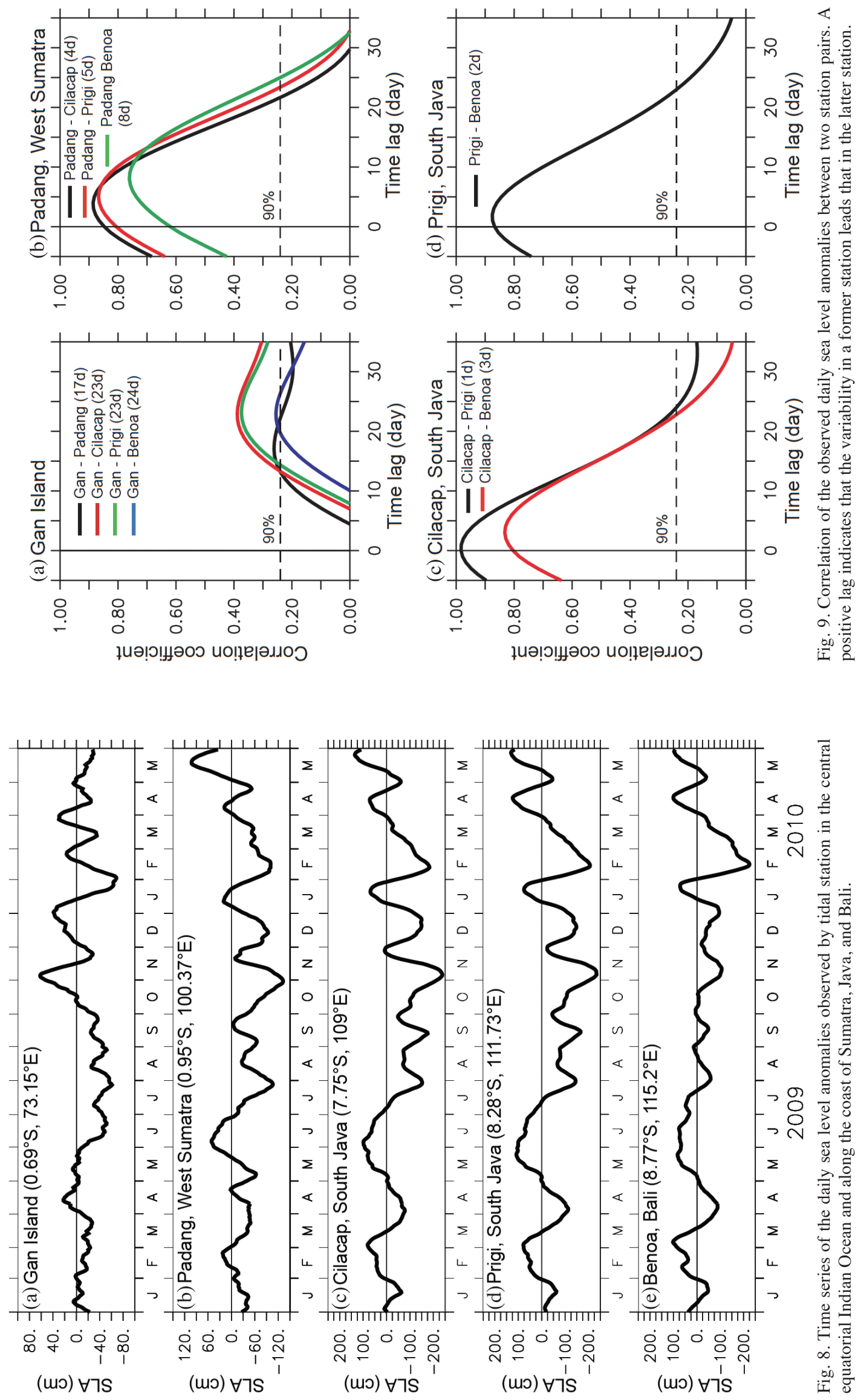
first two theoretical baroclinic modes of the Kelvin waves (Gill 1982) and is in agreement with the previous observations in this region (Sprintall et al. 1999; Iskandar et al. 2005, 2014; Drushka et al. 2010). Note that the theoretical phase speed of the first three baroclinic modes Kelvin waves estimated using vertical stratification averaged along the equatorial Indian Ocean are 2.83, 1.80, and $1.26 \mathrm{~m} \mathrm{~s}^{-1}$, respectively (Drushka et al. 2010).

\section{CONCLUSION}

The SJCC is one of the poorest observed eastern boundary current systems. The RAMA project makes it possible for the first time to observe intensively this boundary current system using ADCP moored off South Java. In this study, we utilized the ADCP data moored at $106.75^{\circ} \mathrm{E}, 8.5^{\circ} \mathrm{S}$ off South Java and ADCP mounted along the equator at 80.5 and $90^{\circ} \mathrm{E}$ to explore the dynamics of the SJCC (Fig. 1).

The observed zonal currents off South Java reveal robust intraseasonal variations from the surface down to about $100 \mathrm{~m}$ depth. These intraseasonal zonal currents are coherent with the alongshore winds off South Java (Figs. 2a - b). However, the alongshore winds alone could not explain observed strong eastward zonal currents, indicating remote forcing may play a role. Meanwhile, the observed meridional currents have a weaker amplitude and a shorter time-scale variation (Figs. 2c-d). The vertical profile of the observed zonal currents indicates that the core of the SJCC is located at depth of about $40 \mathrm{~m}$ (Fig. 3), and it is in agreement with previous observation (Sprintall et al. 1999). The spectral analysis shows that the intraseasonal zonal currents off South Java are characterized by 70 - 100 day variations, while the meridional currents are dominated by 50 - 70 day variations (Fig. 4). Previous modeling study has shown that the upper layer zonal currents off South Java, which are correspond to the SJCC, have intraseasonal variation at period of about 90 days, while the deeper layer oscillates at period of about 60 days (Iskandar et al. 2006).

The SJCC variations are highly correlated with equatorial zonal currents observed in the central and eastern ba$\sin$. The lag correlation analysis indicates that the observed zonal current variations off South Java lag those observed in the 80.5 and $90^{\circ} \mathrm{E}$ by about 18 and 14 days, respectively (Fig. 6). This indicates that there is an eastward propagating signal with phase speed of about $2.37 \mathrm{~m} \mathrm{~s}^{-1}$, which is closely corresponding to the first baroclinic Kelvin waves. Further analysis reveals that the observed eastward and westward zonal currents off South Java are well correlated with the surface winds, SSHA and near-surface currents observed in the equatorial Indian Ocean and along the coast of Sumatra and Java (Fig. 7). The correlation between the SJCC and the surface winds indicates that both remote and local wind forcing play a role in generating the SJCC variations. The oceanic response to the wind forcing can be interpreted in term of wind-forced equatorial Kelvin waves. The lag correlation analysis clearly shows that the SJCC variations are associated with wind-forced Kelvin waves generated in the equatorial Indian Ocean. These waves are propagating eastward along the equator. Once they reached the western coast of Sumatera, part of the energy is propagating poleward along the coastal wave-guide as coastal Kelvin waves. The remaining part is reflected back into the interior Indian Ocean as westward propagating Rossby waves.

A series of sea level data observed by the tidal stations along the equatorial and coastal wave guides further indicates the eastward propagating signals from the equatorial region to the SJCC regions (Fig. 9). Lag correlation analysis on the time series of the observed sea level for each station pair indicates robust eastward propagating signal originated from the equator with phase speed of $2.67 \pm 0.31 \mathrm{~m} \mathrm{~s}^{-1}$. This estimated phase speed close to the theoretical phase speed of the first baroclinic Kelvin waves. Therefore, we may conclude that the SJCC variations are associated with eastward propagating first baroclinic mode of the Kelvin waves. Note that the role of local wind forcing is not negligible.

Acknowledgements We thank the anonymous reviewers for constructive comments and suggestions on the earlier versions of this manuscript. We are indebted to RAMA project that provide the ADCP data and the University of Hawaii Sea Level Center that provide observed tide gauge data. We thank Prof. Yukio Masumoto for useful discussions during the course of this work. The first author is supported by the Ministry of Research, Technology and Higher Education, Republic of Indonesia through a "Pendidikan Magister Menuju Doktor untuk Sarjana Unggul (PMDSU)". Part of this study is supported by the Ministry of Research, Technology and Higher Education, Republic of Indonesia through a "Penelitian Berbasis Kompetensi 2018 (0094/ UN9/SB3.LP2M.PT/2018)".

\section{REFERENCES}

Bonjean, F. and G. S. E. Lagerloef, 2002: Diagnostic model and analysis of the surface currents in the tropical Pacific Ocean. J. Phys. Oceanogr., 32, 2938-2954, doi: 1 0.1175/1520-0485(2002)032<2938:DMAAOT>2.0.C O;2. [Link]

Drushka, K., J. Sprintall, S. T. Gille, and I. Brodjonegoro, 2010: Vertical Structure of Kelvin Waves in the Indonesian Throughflow Exit Passages. J. Phys. Oceanogr., 40, 1965-1987, doi: 10.1175/2010JPO4380.1. [Link]

Ducet, N., P. Y. Le Traon, and G. Reverdin, 2000: Global high-resolution mapping of ocean circulation from TOPEX/Poseidon and ERS-1 and -2. J. Geophys. Res., 105, 19477-19498, doi: 10.1029/2000JC900063. [Link]

Gill, A. E., 1982: Atmosphere-Ocean Dynamics, Vol. 30 , 
Academic Press, San Diego, California, 662 pp.

Iskandar, I., W. Mardiansyah, Y. Masumoto, and T. Yamagata, 2005: Intraseasonal Kelvin waves along the southern coast of Sumatra and Java. J. Geophys. Res., 110, doi: 10.1029/2004JC002508. [Link]

Iskandar, I., T. Tozuka, H. Sasaki, Y. Masumoto, and T. Yamagata, 2006: Intraseasonal variations of surface and subsurface currents off Java as simulated in a highresolution ocean general circulation model. J. Geophys. Res., 111, doi: 10.1029/2006JC003486. [Link]

Iskandar, I., Y. Masumoto, and K. Mizuno, 2009: Subsurface equatorial zonal current in the eastern Indian Ocean. J. Geophys. Res., 114, doi: 10.1029/2008JC005188. [Link]

Iskandar, I., Y. Masumoto, K. Mizuno, H. Sasaki, A. K. Affandi, D. Setiabudidaya, and F. Syamsuddin, 2014: Coherent intraseasonal oceanic variations in the eastern equatorial Indian Ocean and in the Lombok and Ombai Straits from observations and a high-resolution OGCM. J. Geophys. Res., 119, 615-630, doi: 10.1002/2013jc009592. [Link]

Kalnay, E., M. Kanamitsu, R. Kistler, W. Collins, D. Deaven, L. Gandin, M. Iredell, S. Saha, G. White, J. Woollen, Y. Zhu, M. Chelliah, W. Ebisuzaki, W. Higgins, J. Janowiak, K.C. Mo, C. Ropelewski, J. Wang, A. Leetmaa, R. Reynolds, R. Jenne, and D. Joseph, 1996: The NCEP/NCAR 40-year reanalysis project. Bull. Amer. Meteorol. Soc., 77, 437-472, doi: 10.1175/1520-0477( 1996)077<0437:TNYRP>2.0.CO;2. [Link]

Kim, W., S. W. Yeh, J. H. Kim, J. S. Kug, and M. Kwon, 2011: The unique 2009-2010 El Niño event: A fast phase transition of warm pool El Niño to la Niña. Geophys. Res. Lett., 38, doi: 10.1029/2011GL048521. [Link]

Masumoto, Y., H. Hase, Y. Kuroda, H. Matsuura, and K. Takeuchi, 2005: Intraseasonal variability in the upper layer currents observed in the eastern equatorial Indian Ocean. Geophys. Res. Lett., 32, L02607, doi: 10.1029/2004GL021896. [Link]

McPhaden, M. J., G. Meyers, K. Ando, Y. Masumoto, V. S. N. Murty, M. Ravichandran, F. Syamsudin, J. Vi- alard, L. Yu, and W. Yu, 2009: RAMA: The Research Moored Array for African-Asian-Australian Monsoon Analysis and Prediction. Bull. Amer. Meteorol. Soc., 90, 459-480, doi: 10.1175/2008BAMS2608.1. [Link]

Nagura, M. and M. J. Mcphaden, 2008: The dynamics of zonal current variations in the central equatorial Indian Ocean. Geophys. Res. Lett., 35, doi: 10.1029/2008GL035961. [Link]

Qiu, B., M. Mao, and Y. Kashino, 1999: Intraseasonal Variability in the Indo-Pacific Throughflow and the Regions Surrounding the Indonesian Seas. J. Phys. Oceanogr., 29, 1599-1618, doi: 10.1175/1520-0485(1999)029<15 99:IVITIP>2.0.CO;2. [Link]

Quadfasel, D. and G. R. Cresswell, 1992: A note on the seasonal variability of the South Java Current. J. Geophys. Res., 97, 3685, doi: 10.1029/91JC03056. [Link]

Saji, N. H., B. N. Goswami, P. N. Vinayachandran, and T. Yamagata, 1999: A dipole mode in the tropical Indian Ocean. Nature, 401, 360-363, doi: 10.1038/43854. [Link]

Sprintall, J., J. Chong, F. Syamsudin, W. Morawitz, S. Hautala, N. Bray, and S. Wijffels, 1999: Dynamics of the South Java Current in the Indo-Australian Basin. Geophys. Res. Lett., 26, 2493-2496, doi: 10.1029/1999GL002320. [Link]

Sprintall, J., S. E. Wijffels, R. Molcard, and I. Jaya, 2009: Direct estimates of the Indonesian throughflow entering the Indian Ocean: 2004-2006. J. Geophys. Res., 114, doi: 10.1029/2008JC005257. [Link]

Sprintall, J., S. Wijffels, R. Molcard, and I. Jaya, 2010: Direct evidence of the South Java Current system in Ombai Strait. Dyn. Atmos. Oceans, 50, 140-156, doi: 10.1016/j.dynatmoce.2010.02.006. [Link]

Thomson, R. E. and W. J. Emery, 2004: Data Analysis Methods in Physical Oceanography, Third Edition, Elsevier B.V., New York, 728 pp, doi: 10.1016/C20100-66362-0. [Link]

Wyrtki, K., 1962: The upwelling in the region between java and Australia during the south-east monsoon. Mar. Freshw. Res., 13, 217-225, doi: 10.1071/MF9620217. [Link] 